\section{Bioética e estruturas deliberativas alavancas propulsoras de educação emancipadora}

\section{Costa, Tânia Mara Borges da}

Doutoranda e Membro do Grupo de Estudos, Pesquisa e Extensão em Políticas Públicas, Direito à saúde e Bioética BIOGEPE. da Faculdade de Direito de Vitória (FDV). Email: tborgesdacosta@gmail.com

\section{Bussiguer, Elda Coelho de Azevedo}

Livre Docente pela Universidade do Rio de Janeiro UniRio. Doutora em Bioética pela Universidade de Brasília - UnB. Mestre em Direitos e Garantias Fundamentais pela Faculdade de Direito de Vitória - FDV. Coordenadora do Programa de Pós-Graduação em Direito da Faculdade de Direito de Vitória - FDV. Editora da Revista Direitos e Garantias Fundamentais (QUALIS A 1). Coordenadora do Grupo do BIOGEPE - Grupo de Estudos, Pesquisa e Extensão em Políticas Públicas, Direito à saúde e Bioética. Membro do Conselho científico da Sociedade Brasileira de Bioética.

PALAVRAS CHAVE: PEC 55/17; educação emancipadora; bioética; participação popular; plebiscitos e referendos.

INTRODUÇÃO: O gasto público mínimo com educação, estabelecido no Artigo 212 da Constituição Federal de 1988 (CF/88) é de 18\% da Receita Líquida de Impostos (RLI). A PEC 241/2016 e 55/2017 congela estes recursos por 20 anos, para 2017 previu 18\% da RLI. Com Rossi e Dweck ((2016), observa-se que a PEC 55 previu que em 2017 o gasto com educação seria de $18 \%$ da RLI, e com saúde $15 \%$ da RCL. A partir de então, ambos terão piso, o gasto em 2017 reajustado pela inflação, congelado no patamar de 2017. Piso mínimo, deslizante, caindo ao longo do tempo, em proporção das receitas e do PIB. Previsto o mínimo para educação de 14,4\% da RLI em 2026 e 11,3\% em 2036. Neste sentido, o objetivo aqui é refletir sobre este congelamento face à Bioética e suas estruturas deliberativas como espaços institucionais legítimos, alavancas necessárias, propulsoras de uma educação emancipadora, sob o método dialético qualitativo e documental. Os resultados evidenciam política regulatória ilegítima e excludente e, Costa (2016) analisa cortes orçamentários por Decreto Presidencial, em 2015, reduzindo 1,9 bilhão por mês nas despesas. Só na Pasta da Educação o corte mensal foi de $\mathrm{R} \$ 500$ milhões, totalizando 11 bilhões. A conduta refletiu-se nos governos estaduais e municipais. Houve greves de professores em 15 estados, com massacre em Paraná tendo mais de 200 feridos, 8 em estado grave. Nos últimos 8 anos, fecharam 16 mil escolas públicas no Brasil, porém, 7 mil escolas privadas foram abertas. O Espírito Santo teve a $6^{a}$ colocação entre os estados com mais escolas desativadas no país, com $34,9 \%$ das escolas públicas e privadas paradas. O índice do país de $28 \%$. Sem consultas populares. Porém a CF/88 vista com Pedra (2018, p. 1), prevê expressamente que uma das formas de exercício da soberania popular é a realização direta de consultas populares, com plebiscitos e referendos. Sob a força destes instrumentos de participação popular, impõe-se saber quais as possibilidades e os limites das transformações constitucionais. Condutas das quais não podem estar dissociadas da necessidade por fundamentações racionais em relação às questões das fragilidades da Bioética e do Direito, fato que Bussinguer (2016) vislumbra em ambas, enquanto áreas do saber, potencialidades que cada uma delas leva para o diálogo e para a construção de uma relação virtuosa, em busca de uma finalidade comum, tendo em vista o alcance de uma justiça justa que considere a incorporação de valores como condição indispensável à efetivação dos Direitos Fundamentais. Conclui-se pela imperiosa materialização da educação objetivando desenvolvimento integral da personalidade humana com pleno exercício de cidadania. E pelo dever da Bioética e de suas estruturas deliberativas atuar como espaços institucionais legítimos, sob a lente da democracia participativa, enquanto alavancas promotoras da participação popular, com plebiscitos e referendos e das múltiplas facetas do controle social, em prol de uma educação emancipadora viabilizando o exigir coletivamente do Estado, práxis e, políticas públicas educacionais éticas, pela existência de vida digna, face às possibilidades e limites das transformações constitucionais, construtoras de educação cidadã sustentável.

\section{REFERÊNCIAS}

[1] BUSSINGUER, Elda Coelho de Azevedo. A teoria da proporcionalidade de Robert Alexy: uma contribuição epistêmica para a construção de uma bioética latinoamericana. 2016.

[2] COSTA, Tânia Mara Borges da. IMPACTOS DA LRF: gastos e endividamento no governo do Espírito Santo. 2016, 65 f. Dissertação (Mestrado em Administração de Empresas) - Fundação Instituto Capixaba de Pesquisas em Contabilidade, Economia e Finanças - FUCAPE, Vitória, 2016. Disponível em: :<http://www.fucape.br/_public/producao_cientifica /8/Disserta\%C3\%A7\%C3\%A3o\%20Tania\%20Mara\%20Borges.pdf >. Acesso em 21 jul $2017 \mathrm{DE}$

[3] ROSSI, Pedro; DWECK, Esther. Impactos do novo regime fiscal na saúde e educação. Cadernos de Saúde Pública, v. 32, p. e00194316, 2016.

[4] PEDRA, Adriano Sant'Ana. A Constituição viva: poder constituinte permanente e cláusulas pétreas na democracia participativa. Editora Lumen Juris, 2018. $5^{\text {a }}$. Ed. 